\title{
Evaluating the potential for the continuous processing of pharmaceutical products - a supply network perspective
}

\author{
JAGJIT SINGH SRAI*, TOMÁS HARRINGTON, LEILA ALINAGHIAN and MARK PHILLIPS \\ *Corresponding author: Jagjit Singh Srai \\ Tel. +44 1223 765601, Fax.+44 1223 464217, email. jss46@cam.ac.uk
}

Centre for International Manufacturing, Institute for Manufacturing (IfM), University of Cambridge, 17 Charles Babbage Road, Cambridge, CB3 OFS, UK

\begin{abstract}
:
This paper presents an approach to evaluating the potential supply chain benefits of adopting continuous processing technologies for a diverse set of pharmaceutical products. The approach integrates upstream 'continuous' processing considerations for the production of active ingredients and final product formulation, with the downstream implications for packing and distribution. Currently, these upstream and downstream operations largely operate as decoupled operations with independent coordination and governance mechanisms, and the approach presented in this paper identifies opportunities for more case-specific integrated end-to-end supply chains enabled by continuous flow technologies. Three specific product (and corresponding processing technology) case studies are used to demonstrate the utility of the approach in assessing the supply network and system integration opportunities that emerge from the continuous processing of pharmaceutical products.
\end{abstract}

KEYWORDS: continuous, supply chains, industrial sub-systems, pharmaceuticals

\section{INTRODUCTION}

In many industries, supply chains have become 'disaggregated', with activities spread across multiple firms and locations, with individual manufacturing sites increasingly geographically distributed. In Pharmaceuticals, this specialisation has been heavily influenced by the separation of unit operations between the discrete steps of Active Pharmaceutical Ingredient (API), Primary Product Formulation, Secondary Pack Processing, and Distribution activities. Indeed within each of these manufacturing supply chain stages, the predominance of batch processing models has meant that existing pharmaceutical supply chains operate in a high inventory, slow response environment. Traditionally, manufacturing supply network design has involved integrating these 
discrete manufacturing activities but has been constrained by the fact key unit operations are run in batch processing modes. However, continuous flow technologies, present new opportunities to the network designer as radically reconfigured supply networks, with genuine flow-through capabilities through to the end-user, become genuine possibilities [1]. In this paper, we develop an approach to assessing the potential for the continuous processing of pharmaceutical products, including specific implications of defined technology developments for three case studies. Thus, potential users of the methodology will include supply chain designers, future product process-engineering developers and those involved in new product business appraisal. The technology focus of each of the case studies is in:

- $\quad$ Case 1 - Anti-retrovirals (ARVs): Firstly, on particle size control and continuous crystallisations to enable better API quality control (especially for high drug loading products). In addition, continuous formulation advances are used to manage the high complexity of product variants, which is a defining characteristic of the product group. The case, therefore, also incorporates considerations on supply models, as case 1-type drug products often tend to be 'made-to-order'. This has led to longer lead times and an inability to meet emergency orders when minimum batch size requirement (5,000 packs) have resulted in 8 month delays between initial orders and initial production for low volume, niche derivatives [2].

- $\quad$ Case 2 - Anti-malarial Artemisinin Combination Therapies (ACTs): continuous synthesis to reduce solvent use (which is a major issue in the current, low yield batch extraction process), reduce lead times and lower production costs. Here, continuous technology 'interventions', from synthesis right through to packaging and labelling, have been considered in developing and assessing a series of alternative supply models [3].

- $\quad$ Case 3 - Diabetes drug, such as Metformin: addressing the need for significant additional capacity, based on future trends, where volume projections suggest a doubling of demand by 2035 . Here, utilising continuous granulation, and moving towards significantly smaller plant footprints with associated capital cost reductions are commercially attractive [1].

Research on the disaggregation of value chains has tended to consider 'industry sectors' as their unit of analysis where changes to industry structure in for example, computing [4] and financial services [5] has been driven by trends in outsourcing and off-shoring which continue to shape modern manufacturing networks.

Within this industry focus, different patterns of specialisation have been identified as firms seek to integrate new external capabilities and capture location benefits [6], [7], [8]. Mudambi and Venzin [9] introduce technology as a key analytical approach to how networks evolve. Within healthcare, and specifically in-vitro diagnostics, the 
disaggregation of value networks has been analysed from an emerging technology context [10]; the healthcare context providing radically different patient-centric supply chain models and potentially novel business models.

From a theoretical perspective, supply chain analysis and design requires a focal firm perspective of an extended network of firms across a defined product category. However, the optimum configuration of these increasingly complex and fragmented networks is particularly challenging where there are 'multiple tiers' of partner firms, spanning component and intermediate goods supply, presenting a multitude of options on location and partnering models [11], [12]. These supply networks comprise of semi-independent sub-systems that have then become part-disconnected with independent governance mechanisms. These sub-systems can, over time frustrate the operation of integrated outcome based supply chains. For these complex multi-tier supply networks, the more holistic approach presented here considers the industrial system design activity as an integrating process that spans the discrete sub-systems that make up the end-to-end supply chain.

\section{NETWORK SYSTEMS ANALYSIS AND INTEGRATION OF SUB-SYSTEMS}

The methodology that is presented here builds on cross-sector observations of complex multi-tier supply networks where sub-systems have evolved as discrete entities [12], and an underlying premise that a whole systems perspective can support a re-examination of end-to-end network design. A re-configuration of the network requires identification of the drivers of, and interactions between, the main sub-systems in these complex, multi-tier supply networks. The attractiveness of applying the sub-systems integration approach will arise in multi-tier supply networks where the production of intermediate goods, as discrete sub-systems, has emerged as a mechanism for the effective organisation of the current industrial system. In Consumer Electronics for example, global scale contract manufacturers now dominate the sector, supplying key components and/or providing final assembly operations. In Aerospace, major component supply chains have emerged that operate as discrete entities; the UK for example is No.2 globally in aerospace manufacture without major final assembly. Intermediate goods supply chains are also prevalent in the textile sector where opportunities for supply network development involve re-integration of discrete operations, with some manufactures considering closed loop supply chains to optimise resource re-use. These reconfiguration options are invariably driven by technology changes.

However, in most sectors sub-systems operate as independent units targeting internal efficiencies, functioning as silos of activity, mirroring the functional units seen in large organisations. This internal sub-system focus can work to the detriment of the end-to-end supply network. In highly regulated environments, regulation can 
inadvertently 'lock-in' this structural development and frustrate end-to-end supply chain optimisation. In Pharmaceuticals, the sub-system of clinical supply often imposes production process and consequent regulatory constraints for the commercial supply chain.

The reconnecting of semi-isolated sub-systems presents opportunities for an end-to-end supply network perspective, connecting upstream and downstream elements. This approach to supply network integration and optimisation can inform the product-process technology agenda. Alternative production processing models would target system outcomes that aim to address sub-system constraints, redefining supply network drivers of network performance. Examples of alternative processing models that might support more 'flow-through' end-to-end operations include continuous-processing and crystallisation in previously batch-process-oriented Pharma, additive manufacturing in engineering component manufacture that replaces traditional subtractive processes (e.g. aero-engine casings are now manufactured at the point of final assembly rather than being produced in three separate locations before being shipped to the assembly site), and late product post-dosing finishing models that enable more near-market supply (e.g. in FMCG post dosing used for variant production with reduced lead times; industrial ceramics continuous inkjet variant production in Europe to satisfy SKU proliferation demands [1]). Each of these alternative supply chain models have required significant technology breakthroughs to enable a broader industrial systems optimisation agenda, enabling radically different product quality and/or flexibility (volume, variety) opportunities, potentially enabling previously elusive markets to be served economically.

In this research, we develop an approach to evaluate the system level business opportunities that arise from the continuous processing of pharmaceutical products. To demonstrate the utility of the approach, the three different cases are considered to evaluate the relative benefits of continuous processing.

\section{METHODOLOGY DEVELOPMENT - PHARMA CONTEXT}

While evidence exists for continuous processing delivering financial benefits (mainly for single-purpose plants), these studies have largely been focused at the production and plant level [13], [14], [15], [16] with the overall business case in each case lacking an end-to-end supply network assessment. These case studies are discussed briefly later in this section.

The approach to network design and systems integration extends prior work on industrial systems analysis and supply chain mapping techniques [10],[11],[17] . It involves identifying the drivers of, and interactions between, 
the main sub-systems across the supply network. System boundaries are extended to encompass the end-user, and used to inform potential sub-system trade-offs. A key requirement involves 'technology experts' to evaluate alternative supply network configuration models.

From an end-to-end supply network perspective, four proposed stages of analysis are summarised below;

\section{i. Identifying barriers and opportunities to adopting alternative product-process technologies}

Barriers may be real or perceived and arise from combinations of socio-political, technical and regulatory factors.

Despite such barriers to adoption, there is growing evidence, within industrial setting, that firms are moving towards significant adoption of continuous processing, some examples of which are outlined in table 1.

Table 1. Summary of companies with significant investments in continuous processing

\begin{tabular}{|c|l|}
\hline Company & Summary of Industrial and/or R\&D continuous processing applications \\
\hline Eli Lilly & $\begin{array}{l}\text { Significant R\&D lab capability (Indianapolis, US); Activities involve the design and scale up of fully } \\
\text { continuous processes including reaction, workup, and isolation; Typical research scale throughputs are } \\
1-10 \text { g/h and pilot scale throughputs are 5-15 kg/day [18] }\end{array}$ \\
\hline GSK & $\begin{array}{l}\text { R\&D pilot facility (Stevenage, UK); investing \$50 million to install and validate commercial-scale } \\
\text { continuous processing equipment in Singapore [19] }\end{array}$ \\
\hline Lonza & $\begin{array}{l}\text { Developed micro and mini reactors; Integrated continuous process steps into the manufacture of more } \\
\text { than 43 drug products. New construction of a multi-million euro facility for continuous flow and } \\
\text { microreaction technology (Visp, Switzerland) [20] }\end{array}$ \\
\hline Novartis & $\begin{array}{l}\text { Primary and secondary pilot plant in progress (Basel, Switerland) [19]; 10-year research collaboration } \\
\text { being driven by the Novartis-MIT Center for Continuous Manufacturing (Boston, MA) [21] }\end{array}$ \\
\hline Pfizer & $\begin{array}{l}\text { R\&D facility (Groton, US); In 2007, further } € 11 M \text { investment in continuous kilo lab facilities (Cork, } \\
\text { Ireland) [22] }\end{array}$ \\
\hline Sanofi-Genzyme & Patent protected continuous API manufacturing facility in operation (Haverhill, UK) [23] \\
\hline Sigma Aldrich & $\begin{array}{l}\text { Multi-purpose, medium scale continuous flow plant in operation (Buchs, Switzerland) [24]; estimated } \\
\text { that }>70 \text { products are manufactured continuously at very low volume }\end{array}$ \\
\hline
\end{tabular}

In addition, the academic literature has also reported studies where continuous processing has been shown to have an advantage over batch, in terms of process, economics and volumes.

In their study comparing continuous and batch reactors with respect to nitration and hydrogenation reactions, Calabrese et al. [13] observed a drastic reduction in the hydrogenation reaction, from $10 \mathrm{~h}$ to < 2 minutes, when run in continuous flow. This resulted in overall cost reduction potential, through reduction of catalyst and the smaller equipment footprint required. In their 2007 study, Roberge et al.

[14] studied the economics of three hybrid systems, involving campaigns producing 5 tonnes of an 
isolated intermediate through a multi-stage reaction. It was demonstrated that the best result was found when all of the reaction steps were transferred to a continuous-flow operation. This enabled a potential decrease from 3.5 to 2.0 operators per shift and a $16 \%$ economic gain when all reactions were transferred from batch to continuous flow operations. In addition, Gorsec and Glavic [15] compared continuous and batch operation modes on the basis of economic evaluation and found that the continuous plant is more profitable than batch for all capacities (from 200 tonnes/annum) in the case of single purpose equipment. Finally, in this section, in a batch multi-product plant versus continuous single-product plant study in 2012 (for the production of proteins), Seifert et al. [16] benchmarked four continuous mono-product plants against a multi-product batch plant, for the production of proteins, at volumes in the range of $1,500-6,000 \mathrm{~kg} /$ annum. It was demonstrated that a change from batch to continuous operation resulted in a $>30 \%$ higher net present value at the end of the operating period (i.e. net present value of an investment here tells how a continuous investment compares versus that of the current state batch process)

A number of global initiatives have been commissioned to take on elements of the continuous processing transformation challenge. For example, in technology development, programmes are already underway that are required in continuous manufacturing. These include a UK Centre for Continuous Manufacturing and Crystallisation (CMAC), a US-based Novartis-MIT Center for Continuous Manufacturing, the US Centre for Structured Organic Particulate Systems (cSOPS), Ireland SSPC (Synthesis and Solid State Pharmaceutical Centre), various European consortia, and several prototype equipment developments (e.g., UK CMAC Research Partnership Investment Fund). More recently, a new initiative to developing an E2E Supply Chain "eco-system" that considers technology developments (including continuous processing developments) within new supply chain models and the appropriate regulatory regimes required at an industry sector level have been commissioned (UK ReMediES project) [1].

In terms of an end-to-end assessment, volume and complexity are two key discriminating variables (in many product sectors/categories) that can influence supply network design [25]. In the context of this study, figure 1 sets out, at a conceptual level the opportunity in the batch-continuous context for particular processing models, e.g.

Position $\mathrm{A}$ on the chart focuses on unmet patient needs and affordability for low volume and high variant products. In this space, alternative processing models may be used to serve existing markets more effectively or those that have been previously considered uneconomical 
to serve (delivering unmet end-user needs) driven by new capabilities that create new markets.

Personalised medicines or niche product markets exemplify patient populations where advances in diagnostics, information technologies and digitisation, are enabling more disaggregated value network models. The argument here is that micro-continuous processing may offer solutions and this is being actively pursued by several research centres e.g. CMAC.

- Position B at the centre captures the space where both batch and continuous processing could feasibly work. Here, batch processing may still retain cost advantages over continuous at certain volumes and SKU mixes.

- Position C captures opportunities in terms of cost, flexibility or reliability, where continuous processing may offer advantages over batch at specific higher volumes.

Note: The three positions $A, B$ and $C$ do not relate to the three case studies that are evaluated in section 4, but represent (at a conceptual level) where continuous processing may be beneficial (positions $\mathrm{A}$ and C) and where batch may still be the preferred production model (position B).

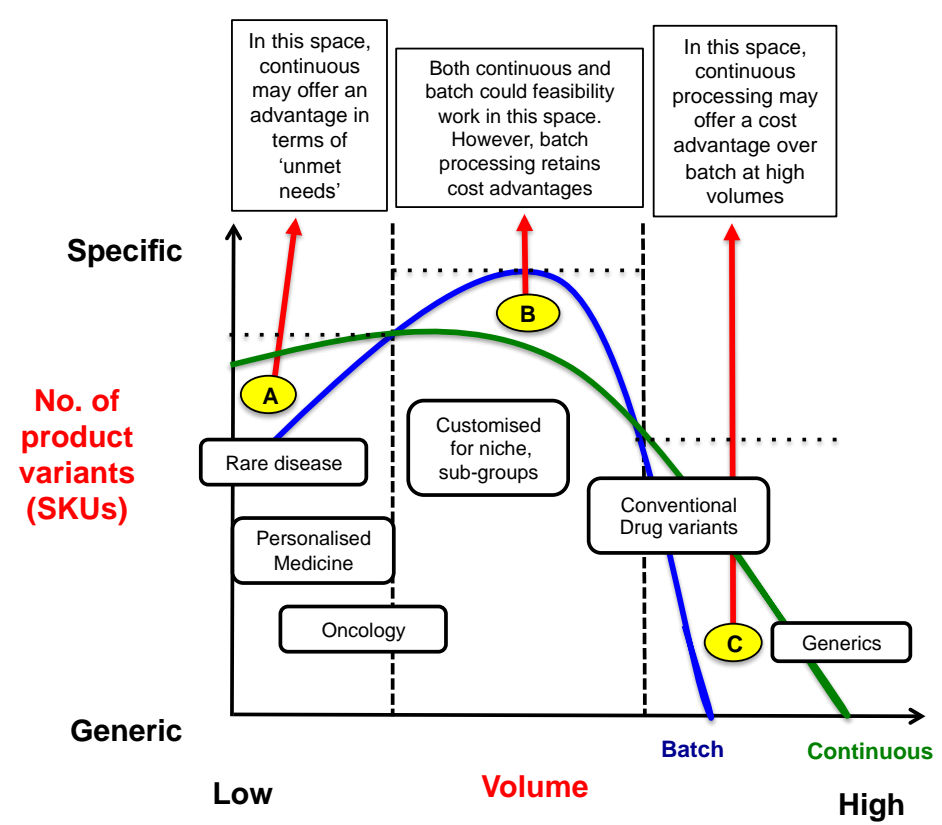

Figure 1 Conceptualising the Volume-Variety Matrix in Pharma, adapted from [25] 


\section{ii. Sub-system identification and analysis; comparison with an end-to-end systems perspective}

Current-state supply and value network mapping techniques are used to define the existing subsystems and the drivers/design factors that predominate in each sub-system. A schematic representation of a typical 'current-state' processing model for pharmaceutical production is presented in figure 2. In reality, this process model will vary case-by-case with some processing activities not required and additional processing steps necessary. Once the current state has been mapped for a specific case, alternative continuous technology processing options and their technology readiness levels may be assessed. An end-to-end network performance analysis is then used to define overall system metrics in order to re-examine these semi-independent sub-systems, challenging the current state configuration design parameters and trade-offs being made.

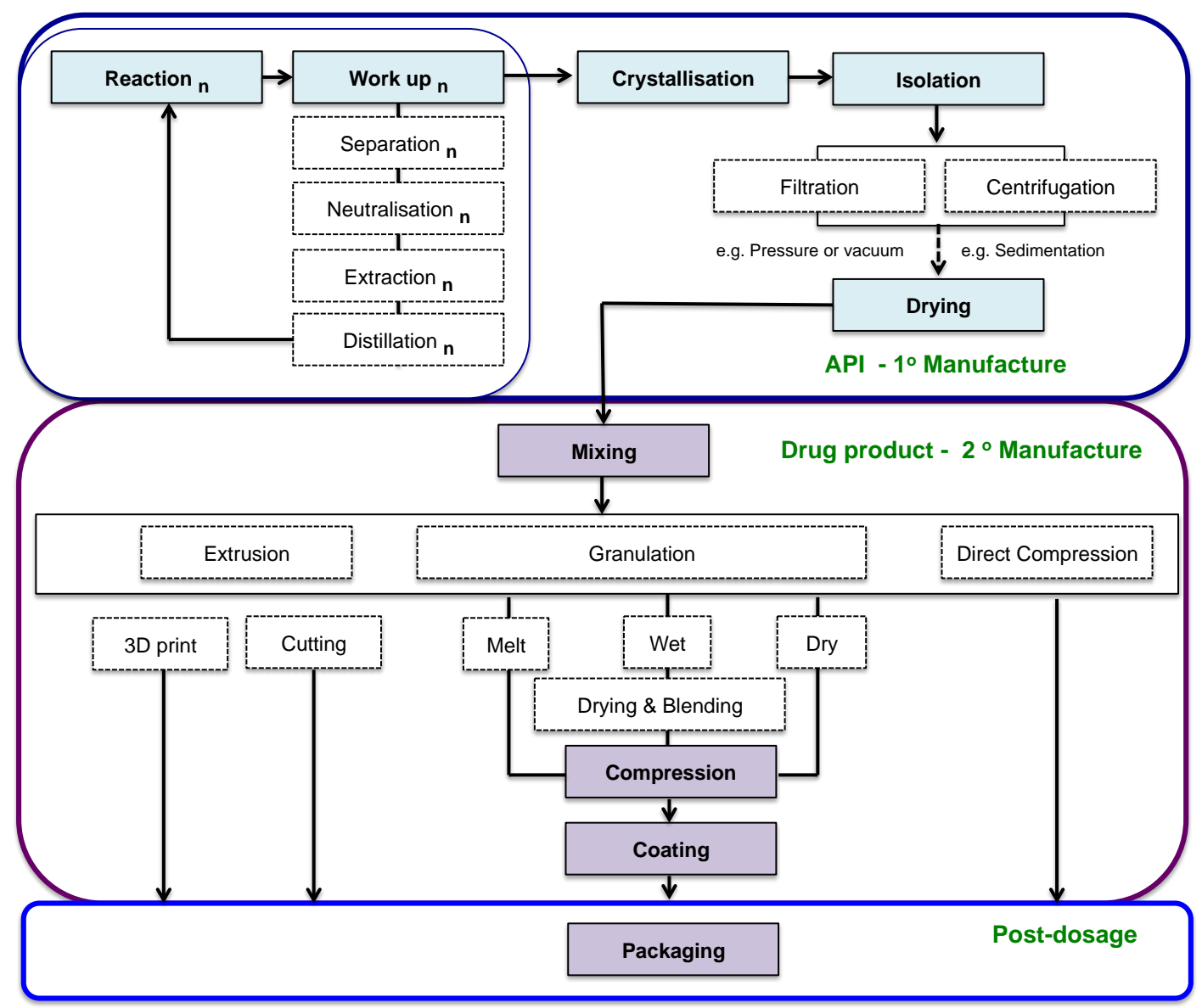

Figure 2 - Schematic of a typical 'current-state' production processing model for pharmaceuticals, Here $n=$ number of repetitions; each repetition may involve a variation in sequence of steps; steps may also consist of linear and/or convergent synthetic routes

\section{iii. $\quad$ Alternative supply network scenario analysis/development}

Supply network scenarios that could emerge by adopting alternative product-process configurations and 
business model innovations are evaluated. Alternatives process and production technologies may be based on emerging technologies or technologies that are still yet to be fully proven or developed but where a supply network assessment identifies system benefits that would emerge from a more 'flowthrough' operation.

In Pharmaceuticals, emerging technologies may be primary production technology based, such as continuous processing and crystallisation of APIs, or secondary continuous processing of final product formulations, or driven by novel routes to market driven by next generation diagnostics. These alternative scenarios may support very different scale production operations, i.e. rather than the large one-size fits all batch plants of today, consideration of dispersed, close-to-market, low-scale integrated plants may be possible through new production technologies. Alternative downstream supply models might also be possible due to advances in patient diagnostics, product re-ordering models or direct replenishment, enabled by e-commerce-based last-mile supply chains. In practice, scenarios depend on various disruptive influences that challenge the current value network model and introduce new possibilities to product or product-service models.

\section{iv. Systems Analysis Analytical Framework}

Finally, an end-to-end supply network systems analysis is undertaken. This process evaluates the alternative scenarios under consideration and how they might redefine existing sub-systems as part of an integrated systems/network re-configuration agenda. The approach involves the assessment of potential benefits of promising scenarios, as a 'delta' analysis on the current state against key system metrics. Whereas system benefits may accrue, the value proposition in making the transformation for key supply network partners is assessed from a business context. For example, the potential impact on revenue, margin, inventory reduction etc, against the investments required, and the technological feasibility of the identified disrupted scenario. These elements of the evaluation are incorporated into a total systems/network analytical framework.

In this paper, we set out the criteria used in each stage of the analysis process, and demonstrate the application of the analytical framework for three pharmaceutical products where 'alternative' continuous processing technologies are being considered.

The Pharmaceutical sector was chosen as it faces multiple challenges; affordability of drugs that question the viability of current operating models, ageing populations that require new approaches to patient care, and major 
technology advances in therapeutics and production technologies, changes that have the potential to generate very different supply network configurations with increasingly distributed information flows and revenue models [1],[26]. The sector also exhibits the criteria of a multi-tier supply network with very well established and independently managed sub-systems of active production, formulation, and final pack, with extended distribution models. Material resource efficiency end-to-end is poor with low patient compliance, compounded by waste in the production process, with moderate production process quality performance (typically 3 sigma). From a product life cycle perspective, Clinical trial supply chains are also typically managed separately from the full-scale commercial supply chains. Regulatory and governance frameworks map these separate and established batchprocess operating models. National governments are increasingly reluctant to accept the cost of new drugs whilst the major primes are managing a more fragmented product portfolio as new technologies are driving smaller volume production runs targeting more niche markets. At a network systems level, the sector suffers from excessively high inventory levels (c. 18 months end-to-end) and slow response to changes in market demand [1], [26], [27], [28].

\section{CASE STUDY ANALYSIS}

The pharmaceutical cases that were chosen represent products at different stages of their product life cycle, have dissimilar product volume and pack complexity profiles, and varying transformation challenges if the alternative process supply network and business case is implemented.

The three cases for taking through the analytical process represent;

- Annual volume ranges that span (1) $<100$ tonnes, (2) mid-range volumes (200-300 tonnes), and (3) volumes substantially $>10,000$ tonnes

- $\quad$ Products that have (1) high levels of unique product and SKU variants, (2) represent a growing number of derivatives and SKUs and (3) modest SKU variants, that emerge from single API multiple dose/format combinations, or multiple API and variant dose/format combinations

- $\quad$ Credible continuous processing options from a chemistry and chemical engineering unit operations perspective

- Reconfiguration drivers that consider both operational and societal benefits

The rationale for each of the selected cases products is further defined in Figure 3, with supporting drivers for change, reported in Table 2.

For each of these products the stage-wise analysis process conducted and findings are described below; 


\section{technologies for specific cases}

The first stage of the analysis considers the potential end-user markets where continuous processing technology might provide additional volume or variant opportunities, in terms of business and/or societal benefits. This may involve delivering unmet user needs (e.g. low volume, niche markets previously unviable) and/or operational variant flexibility benefits, or cost benefits through increased scale.

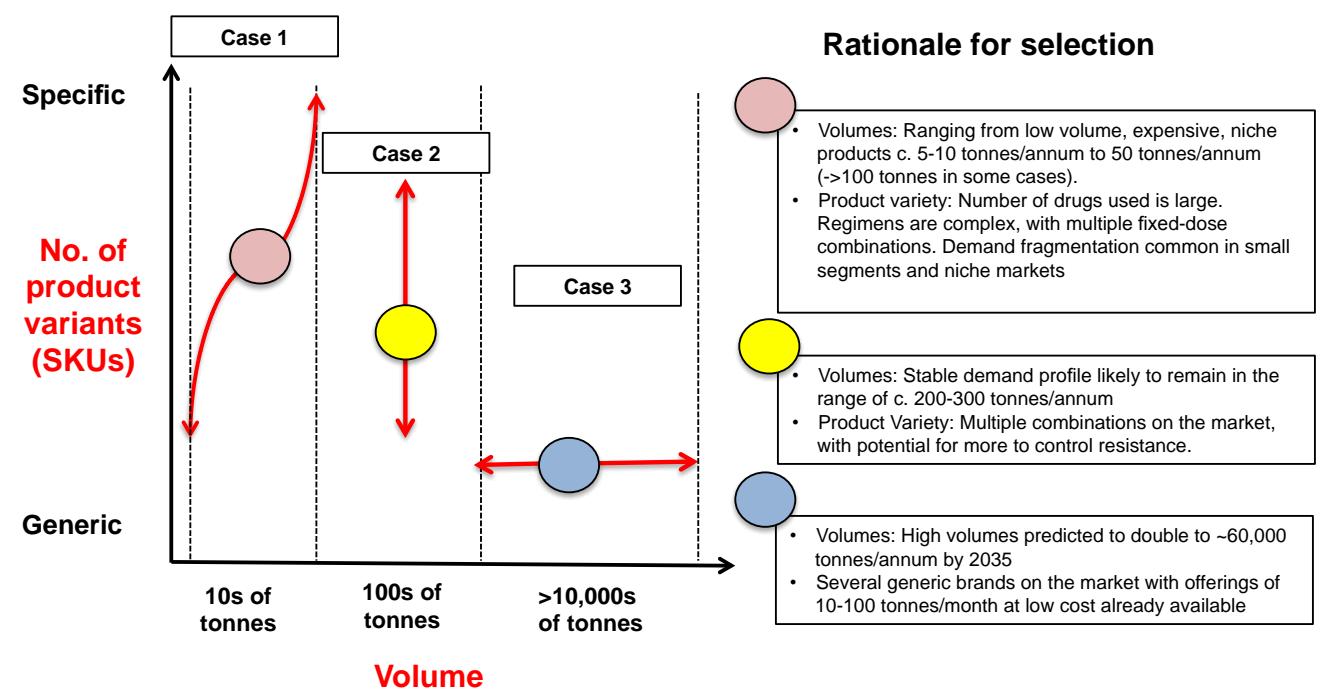

Figure 3 - Volume-product variety profiles for the three specific product-process cases

For each of the three cases, system level barriers and opportunities that might result from adopting more continuous processing are considered from multiple perspectives; new patient populations, government health service providers, and industrial network partners.

In this second stage of the analysis, 'current-state' configuration mapping and basic product-life cycle tools are used to identify the sub-systems across the total supply/value network. The following sub-systems were identified within the Pharmaceutical product sector; Clinical trial Supply Chain process; Primary and Secondary Manufacture, Packing and downstream Distribution.

The specific research questions to be addressed in terms of system optimisation, factors of analysis, and desired outcome across these subsystems were defined as follows; 
- What are the potential patient populations (volume/variety) including unmet needs that are pre-disposed to continuous processing?

- How does continuous processing optimise overall revenue, lead time, investment (and risk) for the target product timeline?

- What are the viable and attractive product-process archetypes and configurations that match target patient populations and manageable product portfolios, and shorten processing cycle times?

- How to better configure a demand driven pack supply chain that match target patient populations and manageable product portfolios?

- What are the new supply network and business models that might emerge from continuous technologies and processes?

For each of the case product groups, technical experts were used to collate standard operational data, current and alternative/future processing scenarios, and wider 'societal-importance' considerations that may influence the reconfiguration opportunity. Societal importance is based on developing the case for delivering more affordable drugs, meeting unmet needs or addressing new patient populations.

The results from this stage of the analysis are set out in Table 2 below.

(iii) Alternative supply network scenario analysis/development

In Table 2, an initial assessment of future/alternative processing models was conducted where alternative chemical process scenario analysis considered opportunities for more flow-through continuous processing. These scenarios are then evaluated in terms of the 'delta' or relative benefits against key system level operational benefits that might emerge from continuous processing. This step in the process generates 'the delta' or potential step change possibilities in the key metric(s) or impact variable under consideration (see table 3) 
Table 2 Analysis of Supply Network Operational Parameters

\begin{tabular}{|c|c|c|c|c|}
\hline Data set & Parameters & Case 1 & Case 2 & Case 3 \\
\hline \multirow{4}{*}{$\begin{array}{l}\text { Societal } \\
\text { importance } \\
\text { (drivers for } \\
\text { change) }\end{array}$} & Disease Area & HIV & Malaria & Diabetes \\
\hline & Patient population & $\begin{array}{l}\text { Estimated to be up to } 35 \mathrm{M} \\
\text { [29] }\end{array}$ & $\begin{array}{c}220 \mathrm{M}[35], \text { projected to } \\
\text { increase to over } 500 \mathrm{M} \text { by } 2018 \\
{[36]}\end{array}$ & $\begin{array}{c}387 \mathrm{M} \text {, of which } 90 \% \text { is Type } 2 \\
\text { diabetes [43] }\end{array}$ \\
\hline & Unmet needs & $\begin{array}{l}\text { Treatment regimes complex. } \\
\text { Managing complexity and } \\
\text { adherence [30]. } \\
\text { Access cost for newer } \\
\text { drugs. }\end{array}$ & $\begin{array}{l}\text { Product Cost high to patient } \\
\text { without subsidy. Significant } \\
\text { security issues. } \\
\text { High counterfeit rates in several } \\
\text { countries [35]. }\end{array}$ & $\begin{array}{l}\text { Growing prevalence in } \\
\text { emerging markets, }>590 \mathrm{M} \\
\text { patients by } 2035 \text { [43]. } \\
\text { Affordability and access to } \\
\text { treatment. }\end{array}$ \\
\hline & Affordability factors & $\begin{array}{c}\text { High cost for new } \\
\text { combination products. } \\
\text { Older drugs for least- } \\
\text { developed countries }<\$ 1 \text { per } \\
\text { day [31] }\end{array}$ & $\begin{array}{l}\text { Subsidy levels, to enable } \\
\text { consumer affordability are } \\
\text { currently high at } \sim 90 \% \text { [37]. } \\
\text { Global funding for malaria, } \\
\text { US } \$ 2.3 B \text { (in 2011) }\end{array}$ & $\begin{array}{c}\text { Major healthcare cost } \\
\text { In 2014, expenditure reached } \\
\text { US } \$ 612 \text { billion [43] }\end{array}$ \\
\hline \multirow{6}{*}{$\begin{array}{l}\text { Operational } \\
\text { Data }\end{array}$} & Volumes (current) & $5-100$ tonnes/a & $\begin{array}{c}200-250 \text { tonnes/a } \\
{[38]}\end{array}$ & 30,000 tonnes/a [44] \\
\hline & $\begin{array}{l}\text { Basic financials: cost; } \\
\text { revenues; margin }\end{array}$ & $\begin{array}{c}\text { Older drugs } \$ 400-1000 / \mathrm{kg} . \\
\text { Opportunities to reduce } \\
\text { costs [32], [33]. } \\
\text { Newer drugs }>\$ 5000 / \mathrm{kg} \\
\end{array}$ & $\begin{array}{c}\text { Plant-derived API costs at } \\
\$ 350-1200 / \mathrm{kg} \text {. } \\
\text { API costs using a bio- } \\
\text { processing route } \$ 400 / \mathrm{kg}[39]\end{array}$ & $\begin{array}{l}\text { Generic; Estimated API costs } \\
\text { at } \$ 5-15 / \mathrm{kg}\end{array}$ \\
\hline & SKU mix & $\begin{array}{c}\text { Multiple classes of drug [30]. } \\
\text { Over } 50 \text { combinations [31] } \\
>100 \text { million packs/a [2] }\end{array}$ & Multiple combinations [35] & $\begin{array}{l}\text { Several generic brands; } 9 \\
\text { FDA approved combinations } \\
\text { [45] and various pack sizes }\end{array}$ \\
\hline & Inventory & $\begin{array}{l}\text { Est. Final product 3-6 } \\
\text { months }\end{array}$ & Est. Final product 3-6 months & Est. Final product 3-6 months \\
\hline & $\begin{array}{l}\text { CapEx delta } \\
\text { (batch -> continuous) }\end{array}$ & $\begin{array}{l}\text { Much existing capacity in } \\
\text { place. Potential } \\
\text { opportunities for reduced } \\
\text { Capex in continuous } \\
\text { formulation of combinations }\end{array}$ & $\begin{array}{l}\text { Potential capex savings if new } \\
\text { capacity is required, based on } \\
\text { design calculations }\end{array}$ & $\begin{array}{c}\text { Alternative chemistry, with } \\
\text { improved kinetics [46] enables } \\
\text { continuous process to deliver } \\
\text { increased capacity at lower } \\
\text { capex. }\end{array}$ \\
\hline & Quality/waste & $\begin{array}{c}\text { High quality API required to } \\
\text { control combination } \\
\text { formulations. Batch API } \\
\text { process have relatively low } \\
\text { yields and high waste. (10s } \\
\mathrm{kg} / \mathrm{kg} \text { output) }\end{array}$ & $\begin{array}{c}\text { Current process highly variable } \\
\text { quality and very low yields } \\
\text { (cultivation and extraction) and } \\
\text { high waste (100s kg/kg output) } \\
{[38]}\end{array}$ & $\begin{array}{l}\text { Current processes have high } \\
\text { yields and purity (>95\%) [47] }\end{array}$ \\
\hline \multirow[t]{2}{*}{$\begin{array}{l}\text { Processing } \\
\text { model }\end{array}$} & Current & $\begin{array}{c}\text { Multi-stage batch. } \\
\text { Opportunities to reduce cost } \\
\text { [29], } \\
\text { No. of drugs / regimens } \\
\text { complex [30] }\end{array}$ & $\begin{array}{l}\text { Plant extraction / purification } \\
\text { and multi-stage batch [38]. } \\
\text { Delivery performance poor [36] }\end{array}$ & $\begin{array}{c}\text { Very simple batch process. } \\
\text { Low cost already available } \\
\text { [47] }\end{array}$ \\
\hline & Future & $\begin{array}{l}\text { Potential for continuous API } \\
\text { and continuous secondary. } \\
\text { Service improvement } \\
\text { opportunities [34] }\end{array}$ & $\begin{array}{c}\text { Several alternative synthetic } \\
\text { routes with improved kinetics } \\
\text { enable continuous API } \\
\text { processing [38]. } \\
\text { Potential for continuous } \\
\text { secondary processing [40], } \\
\text { [41], [42] }\end{array}$ & $\begin{array}{c}\text { High probability to be } \\
\text { amenable to continuous API } \\
\text { [46] and alternative } \\
\text { formulation process enables } \\
\text { secondary continuous } \\
\text { processing [48] }\end{array}$ \\
\hline $\begin{array}{l}\text { Potential } \\
\text { opportunity }\end{array}$ & $\begin{array}{l}\text { Evaluation summary } \\
\text { of opportunities from } \\
\text { continuous } \\
\text { manufacturing }\end{array}$ & $\begin{array}{l}\text { Improved API control to } \\
\text { enable new formulation } \\
\text { opportunities. Potential for } \\
\text { new combination products to } \\
\text { improve adherence and } \\
\text { treatment }\end{array}$ & $\begin{array}{l}\text { Potential for improved quality } \\
\text { and supply reliability, and to } \\
\text { reduce overall product cost. }\end{array}$ & $\begin{array}{c}\text { Reduced capital cost for } \\
\text { increased capacity required. }\end{array}$ \\
\hline
\end{tabular}

Note.

Case 1 (HIV) is supported by industrial practice/interviews and secondary referenced data sources.

Case 2 (Malaria) assertions are based on specific design calculations, corroborated by secondary data sources and industrial practice/interviews.

Case 3 is based on secondary data and supported by industrial practice/interviews.

Appendix A sets out the expert informants, by role, and their contribution to the 3 cases 
Table 3. Potential benefits of continuous manufacturing in the pharmaceutical industry (Key: ++ Significant opportunity; + some opportunity; = Neutral / borderline; - penalty in moving to continuous)

\begin{tabular}{|c|c|c|c|}
\hline Impact variable & Case 1 & Case 2 & Case 3 \\
\hline$\Delta$ Inventory & $\begin{array}{l}+ \\
\text { Complexity lies in number of } \\
\text { combinations used in therapy. } \\
\text { Current batch processing } \\
\text { results in high inventory. } \\
\text { Continuous processing better } \\
\text { matched to demand, can } \\
\text { reduce inventory in } \\
\text { manufacturing and supply } \\
\text { chain }\end{array}$ & $\begin{array}{l}\mathbf{+ +} \\
\text { Current processes rely on } \\
\text { annual harvesting, } \\
\text { bioprocessing and batch } \\
\text { processing. Continuous } \\
\text { processing can significantly } \\
\text { reduce inventory. }\end{array}$ & $\begin{array}{l}+ \\
\text { Likely to have benefits from } \\
\text { better E2E management given } \\
\text { potential scale of supply } \\
\text { required in future }\end{array}$ \\
\hline$\Delta$ Lead time supply & $\begin{array}{l}+ \\
\text { High variety of combinations. } \\
\text { Cycle time opportunities (as } \\
\text { above) }\end{array}$ & $\begin{array}{l}+ \\
\text { Opportunity to reduce overall } \\
\text { lead-time to final product } \\
\text { (from } 10 \text { s of months to weeks) }\end{array}$ & $\begin{array}{l}+ \\
\text { API content high. Having a } \\
\text { stable supply offers potential for } \\
\text { downstream improvement }\end{array}$ \\
\hline$\Delta$ Lead time to market & $\begin{array}{l}\text { - } \\
\text { Priority regulatory review (for } \\
\text { new products) may limit } \\
\text { opportunities in primary } \\
+ \\
\text { Opportunities for continuous } \\
\text { secondary to develop } \\
\text { combination products }\end{array}$ & $\begin{array}{l}\text { = } \\
\text { Opportunities only if new } \\
\text { derivatives are developed. } \\
\text { Some opportunities for } \\
\text { continuous secondary to } \\
\text { develop new combination } \\
\text { products }\end{array}$ & $\begin{array}{l}= \\
\text { API is already generic. } \\
\text { In terms of clinical trials, not } \\
\text { relevant unless part of a new } \\
\text { combination. } \\
\text { Smaller footprint of a continuous } \\
\text { plant could provide shorter lead } \\
\text { time to new capacity }\end{array}$ \\
\hline$\Delta$ Scale-up & $\begin{array}{l}+ \\
\text { Further process development } \\
\text { required before scale-up. } \\
\text { Continuous processing may } \\
\text { enable better API quality } \\
\text { control for formulation } \\
\text { (especially for high drug } \\
\text { loading products) } \\
\text { - } \\
\text { The complexity of synthetic } \\
\text { routes may limit opportunities }\end{array}$ & $\begin{array}{l}+ \\
\text { Further process development } \\
\text { required before scale-up. } \\
\text { Continuous processing may } \\
\text { enable better API quality } \\
\text { control on scale-up of that } \\
\text { process. }\end{array}$ & $\begin{array}{l}\text { ++ } \\
\text { Further process development } \\
\text { required before scale-up. } \\
\text { Opportunities exist as global } \\
\text { capacity is projected to double. } \\
\text { Continuous plant for both API } \\
\text { and formulation should be } \\
\text { feasible for a lower footprint and } \\
\text { reduce capital cost }\end{array}$ \\
\hline $\begin{array}{l}\Delta \text { Volume flexibility } \\
(\text { mix/volume })\end{array}$ & $\begin{array}{l}+ \\
\text { Volume (flexibility) and mix } \\
\text { demands create opportunities } \\
\text { for both API and secondary } \\
\text { formulation. Continuous } \\
\text { formulation offers possibility of } \\
\text { new ways to manages } \\
\text { volume/mix }\end{array}$ & $\begin{array}{l}+ \\
\text { High volume with relatively } \\
\text { stable demand. Potential for } \\
\text { more combinations in future to } \\
\text { address drug resistance will } \\
\text { add to mix. Continuous } \\
\text { formulation may enable better } \\
\text { control. }\end{array}$ & $\begin{array}{l}+ \\
\text { Demand steadily growing. High } \\
\text { volume flexibility with limited mix }\end{array}$ \\
\hline $\begin{array}{c}\Delta \text { Process control; reliability; } \\
\text { safety }\end{array}$ & $\begin{array}{l}+ \\
\text { Continuous processing may } \\
\text { enable better API quality } \\
\text { control for high drug-load } \\
\text { combination products }\end{array}$ & $\begin{array}{l}+ \\
\text { Opportunities to remove } \\
\text { significant solvent use (in } \\
\text { extraction) and improve } \\
\text { overall process reliability }\end{array}$ & $\begin{array}{l}\text { = } \\
\text { Currently a very simple process. } \\
\text { As it is a large volume process, } \\
\text { continuous may offer } \\
\text { opportunities to reduce in- } \\
\text { process solvent and reagent } \\
\text { inventories }\end{array}$ \\
\hline$\Delta$ Quality; purity; counterfeit & $\begin{array}{l}+ \\
\text { Continuous processing should } \\
\text { enable better API quality } \\
\text { control and consistency } \\
\text { Products typically have high } \\
\text { drug loading, so API quality } \\
\text { and physical properties are } \\
\text { more important }\end{array}$ & $\begin{array}{l}+ \\
\text { Continuous processing should } \\
\text { enable better API quality } \\
\text { control and more consistent } \\
\text { purity. } \\
\text { Continuous printing } \\
\text { technologies and 'serialisation' } \\
\text { offer solutions to counterfeiting }\end{array}$ & $\begin{array}{l}= \\
\text { Very simple existing process, } \\
\text { with high yield and quality. }\end{array}$ \\
\hline$\Delta$ Yield & $\begin{array}{l}\text { = } \\
\text { Further analysis required on } \\
\text { potential delta v. batch } \\
\text { processing with respect to } \\
\text { overall yield }\end{array}$ & $\begin{array}{l}\text { ++ } \\
\text { Significant Opportunities to } \\
\text { use continuous processes to } \\
\text { recover waste-streams and } \\
\text { improve overall yield }\end{array}$ & $\begin{array}{l}= \\
\text { Yield already high circa. 96\%, } \\
\text { limited opportunity for further } \\
\text { improvement }\end{array}$ \\
\hline $\begin{array}{c}\Delta \text { IP protection/ } \\
\text { extension/counterfeit }\end{array}$ & $\begin{array}{l}+ \\
\text { Opportunities for IP protection } \\
\text { and counterfeit prevention }\end{array}$ & $\begin{array}{l}+ \\
\text { Significant counterfeit } \\
\text { prevention opportunity in } \\
\text { packaging }\end{array}$ & $\begin{array}{l}+ \\
\text { API off patent with multiple } \\
\text { suppliers. Continuous secondary } \\
\text { may offer new IP }\end{array}$ \\
\hline $\begin{array}{c}\Delta \text { Cost (process/ } \\
\text { packaging/transport) }\end{array}$ & $\begin{array}{l}+ \\
\text { Opportunities in formulation } \\
\text { and secondary processing due } \\
\text { to wide number of variants, } \\
\text { combinations, strengths, pack } \\
\text { sizes and country } \\
\text { requirements }\end{array}$ & $\begin{array}{l}\mathbf{+ +} \\
\text { A major driver for WHO as } \\
\text { current subsidy levels remain } \\
\text { high }(>90 \%)[21]\end{array}$ & $\begin{array}{l}\text { Costs already low. Some } \\
\text { opportunity to improve } \\
\text { performance in e.g. continuous } \\
\text { pack around flexibility and } \\
\text { service }\end{array}$ \\
\hline$\Delta$ Investment cost & $\begin{array}{l}+ \\
\text { Potential for lower investment } \\
\text { cost for additional secondary } \\
\text { capacity and packaging }\end{array}$ & $\begin{array}{l}+ \\
\text { Continuous processes have } \\
\text { fast kinetics, enabling smaller } \\
\text { plant size. Potential for lower }\end{array}$ & $\begin{array}{l}+ \\
\text { Potential for lower investment } \\
\text { cost for more capacity }\end{array}$ \\
\hline
\end{tabular}




\begin{tabular}{|c|c|c|c|}
\hline & & $\begin{array}{l}\text { investment cost for more } \\
\text { capacity }\end{array}$ & \\
\hline$\Delta$ Fiscal $/$ tax & $\begin{array}{l}= \\
\text { Potential opportunity with } \\
\text { NGOs, governments for major } \\
\text { programmes }\end{array}$ & $\begin{array}{l}= \\
\text { Potential opportunity with } \\
\text { NGOs, governments for major } \\
\text { programmes }\end{array}$ & $\begin{array}{l}+ \\
\text { Potential opportunity to locate } \\
\text { manufacture in local markets }\end{array}$ \\
\hline $\begin{array}{l}\Delta \text { Environmental } \\
\text { impact/solvent }\end{array}$ & $\begin{array}{l}+ \\
\text { Opportunity to reduce reagent } \\
\text { and solvents use with } \\
\text { continuous processing }\end{array}$ & $\begin{array}{l}\mathbf{+ +} \\
\text { Solvents (and environmental } \\
\text { impact) a major issue in } \\
\text { current extraction process. } \\
\text { Combinations of } \\
\text { bioprocessing and continuous } \\
\text { processing could potential } \\
\text { reduce solvent demand by } 80 \text { - } \\
90 \% \text {. }\end{array}$ & $\begin{array}{l}+ \\
\text { Some opportunities on specific } \\
\text { continuous technology } \\
\text { adoptions requirements and } \\
\text { routes to manufacture. } \\
\text { Opportunity to further reduce } \\
\text { residual solvent to improve API } \\
\text { quality }\end{array}$ \\
\hline$\Delta$ Viability/adaptability & $\begin{array}{l}\text { Limited studies on alternative } \\
\text { processes to date. Limited } \\
\text { work on continuous } \\
\text { formulation processes }\end{array}$ & $\begin{array}{l}+ \\
\text { Several continuous schemes } \\
\text { have been developed }(30) \\
\text { which demonstrate potential } \\
\text { feasibility and benefits }\end{array}$ & $\begin{array}{l}+ \\
\text { Ease of manufacture (2-step } \\
\text { chemistry) - amenable to smaller } \\
\text { continuous plants }\end{array}$ \\
\hline$\Delta$ Asset utilisation & $\begin{array}{l}= \\
\text { Continuous API likely to be } \\
\text { dedicated v. multi-purpose } \\
\text { batch, so potential for lower } \\
\text { asset utilisation if volume } \\
\text { flexibility is high }\end{array}$ & $\begin{array}{l}\text { = } \\
\text { Continuous API likely to be } \\
\text { dedicated v. multi-purpose } \\
\text { batch, so potential for lower } \\
\text { asset utilisation if volume } \\
\text { flexibility is high }\end{array}$ & $\begin{array}{l}\text { = } \\
\text { Amenable to have multiple } \\
\text { smaller continuous plants close } \\
\text { to target (new) markets }\end{array}$ \\
\hline
\end{tabular}

(iv)

Systems Analysis Analytical Framework

The analytical framework presented in this paper examined the interactions between the sub-systems in Pharma for the three cases, representing dissimilar product examples to demonstrate the utility of the approach.

In this paper, limitations of space constrain the full graphical presentation of the comparative analysis. However, figures 4 and 5 set out impact variables for the three case products in terms of cycle time v. \%inventory for primary/secondary processing and \%Inventory v. service in terms of E2E supply respectively. In assessing the specific continuous interventions for the three cases presented and the potential scale of opportunities across the E2E supply chain [1], significant reductions of up to $50 \%$, in terms of cycle time (starting materials to packed product) and $>65 \%$ reductions of inventory (within primes) are achievable. This, in turn, improves service levels to the patient through the emergence of more demand-driven supply models [1]. 


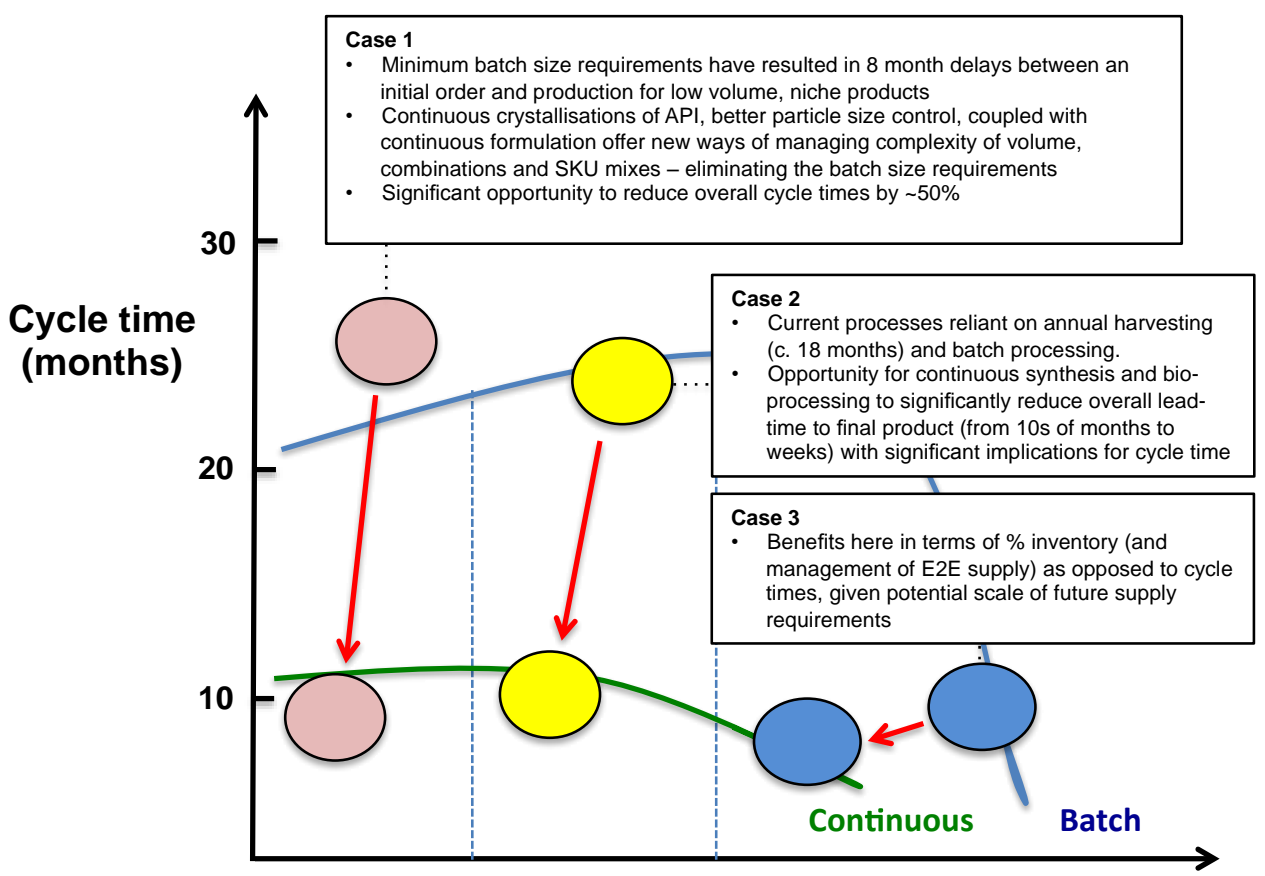

$\%$ Inventory/Cost

Figure 4 - Primary/secondary continuous processing - specific benefits for the 3 cases in terms of improved cycle time

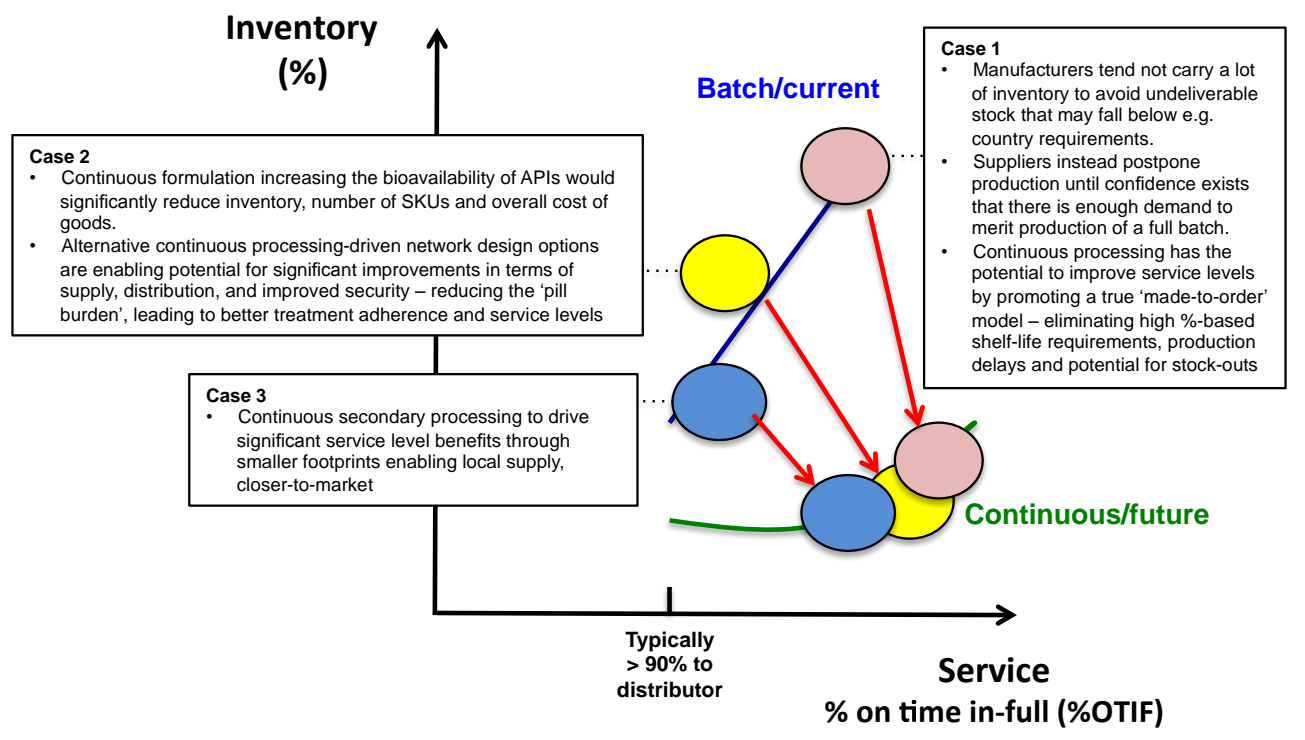

Figure 5. E2E supply through continuous processing - specific benefits for the three cases in terms of inventory and service

Table 4 summarises the analysis for continuous processing across the three case product groups, using the analytical framework in conjunction with considerations of business context and technological readiness. 
Table 4. Analytical framework outputs of potential for continuous processing, coupled with business context weighting and technology feasibility - Cases 1-3

\begin{tabular}{|c|c|c|c|}
\hline Parameters & Case 1 & Case 2 & Case 3 \\
\hline $\begin{array}{ll} & \text { Analytical Framework } \\
& \text { Outputs (delta) } \\
\text { - } & \text { Volume v. Variety } \\
\text { - } & \text { Revenue and Operating costs v. } \\
\text { Time } \\
\text { - } \quad \text { Investment Cost v. Time } \\
\text { - } \quad \text { Quality/Yield v. Inventory/Cost } \\
\text { - } \quad \text { Sycle Time v. Inventory/Cost } \\
\text { - } \quad \text { Inventory (\%) v. Service (On- } \\
\text { Time In -Full/Availability) }\end{array}$ & $\begin{array}{l}\text { Driven by a complex } \\
\text { number of variants: wide } \\
\text { range of regimens, } \\
\text { volumes, combinations, } \\
\text { strengths, pack sizes } \\
\text { and countries }\end{array}$ & $\begin{array}{l}\text { Driven by } \\
\text { opportunities to } \\
\text { significantly reduce } \\
\text { lead-time and increase } \\
\text { service levels. }\end{array}$ & $\begin{array}{l}\text { Driven by the need } \\
\text { for significant } \\
\text { additional capacity. }\end{array}$ \\
\hline $\begin{array}{c}\text { Business } \\
\text { Context Weighting } \\
\text { i.e. potential Manufacturing } \\
\text { Conversion savings (\% of NPS) plus } \\
\text { SC Inventory saving as \% continuous } \\
\text { manufacturing capex }\end{array}$ & $\begin{array}{l}\text { Uncertainty as several } \\
\text { new HIV therapies are in } \\
\text { development, and may } \\
\text { be 'fast tracked' if they } \\
\text { show good performance }\end{array}$ & $\begin{array}{l}\text { Stable demand profile } \\
\text { likely to remain at } 200 \text { - } \\
300 \text { tonnes/a. Driven } \\
\text { by potential for cost } \\
\text { and inventory } \\
\text { reduction. }\end{array}$ & $\begin{array}{l}\text { Driven by volumes, } \\
\text { which are predicted } \\
\text { to double. Potential } \\
\text { for smaller footprint, } \\
\text { lower investment } \\
\text { cost and opportunity } \\
\text { for local supply. }\end{array}$ \\
\hline $\begin{array}{c}\text { Process Manufacturing } \\
\text { Technical feasibility } \\
\text { (Chemistry/ Continuous processing) } \\
\text { Informed by Technology Roadmaps }\end{array}$ & $\begin{array}{l}\text { Multiple drugs using } \\
\text { several stages of } \\
\text { synthesis, which are } \\
\text { often complex. }\end{array}$ & $\begin{array}{l}\text { Several continuous } \\
\text { processes have been } \\
\text { developed which have } \\
\text { demonstrated } \\
\text { potential benefits }\end{array}$ & $\begin{array}{c}\text { Highly amenable, } \\
\text { driven by ease of } \\
\text { chemical } \\
\text { route/manufacture }\end{array}$ \\
\hline
\end{tabular}

Specifically,

- Case 1 may be classed as having medium potential. Whilst there may be opportunities in continuous formulation and tableting processing due to high drug-loading and drug-switching requirements, there remains large uncertainty with respect to the direction future front-line therapies and specific product lifecycle.

- Case 2 has high potential with opportunities to reduce cost and inventory and improve supply chain security.

- Case 3 has the highest potential for a switch to continuous, with simpler chemistry and a significantly growing demand requiring more capacity

From a systems integration perspective, all three cases benefit from more integrated flow-through processing. As supply network design typically promotes flow-through as a principle of operation, and that continuous processing also offers volume flexibility, especially for lower scale production activities, all the continuous processing scenarios score favourably against current batch operations. 


\section{DISCUSSION \& CONCLUSIONS}

This paper extends earlier conceptual developments [25] on the evaluation of continuous processing technologies by applying refined concepts to three specific cases that are being actively explored in the sector. It first explores the relative attractiveness of continuous vs. batch, and sets out the key factors, from an operations/supply-chain perspective, that needs to be considered. These observations are 'generic' in nature but make the case that continuous should be more prevalent in practice than it has been (in addition to being inappropriate in certain instances). The second set of observations, presented here as part of the conclusions, refer to the specific case studies and are very specific in nature. The aim is to explore possible options, and only in specific cases can priorities be discussed or identified.

The analytical approach has been applied in three case studies within the pharmaceutical sector where continuous processing is being actively considered. The analysis identifies reconfiguration opportunities that are driven by alternative product-processing innovations using continuous processing. The three specific case product groups that were considered represent diverse product-patient categories, where continuous processing may benefit a range of new product and patient groups. We conclude that the cases have medium to high potential for continuous processing and that case 3 has the highest potential based on the factors of analysis. In the three cases analysed, the following assessments were generated.

- $\quad$ Case 1 - Anti-retrovirals (ARVs) case study: may be classed as having medium potential, with specific opportunities in continuous crystallisations to enable better API quality control (especially for high drug loading products). Similarly, advances in continuous formulation may support product portfolio complexity management and drug switching requirements. However, there remains large uncertainty with respect to the direction of future front-line therapies and specific product lifecycles.

Discussion: In their recent review paper, Ripin et al. present key procurement and supply chain issues that challenge the timely and reliable delivery of ARVs [2]. Here, the opportunities around continuous formulation confirm new ways of managing the high complexity of volumes, combinations and SKU mixes to enable significant cycle time reductions, given the increasing fragmentation of demand, forecasting inaccuracies, shelf-life requirements and high variety of combinations. The current formulary list for ARVs is wide-ranging and complex - with each regimen having multiple formulations, with single, double or triple fixed-dose combination options. Overall demand continues to be split into smaller and smaller entities, by chemical entity, leading to very low treatment volumes. In terms of these very specialised drugs, it is becoming more and more difficult for manufacturers to retain profitability [2]. The 
case is also presented where pooled demand from three sources is required in order to 'trigger' achievement of the minimum batch size requirements for the product. The process here is lengthy, where examples have been reported of 8-month delays between and initial order and the initial batch production run. It is feasible to eliminate this lead-time and improve security of supply, through adopting smaller volume runs through more continuous routes.

In addition to the extensive drug-switching requirements for HIV as part of treatment regimes, driving product variants and complexity, the high requirements on shelf-life and a rather atypical tender model (where market specific stock is made to contract order) means manufacturers will typically not carry a lot of inventory to avoid undeliverable stock that may fall below e.g. country requirements. Service levels are artificially high (typically $>90 \%$ to distributor) as suppliers tend to postpone any production until confidence exists that there is enough demand to merit a full batch - often leading to delays, stock-outs and less than ideal service levels [2]. In summary, continuous processing has the potential to improve service levels by reducing \% inventory, eliminating minimum batch size requirements and safety stocks - enabling a more 'made-to-order' contract model.

- Case 2 - Anti-malarial Artemisinin Combination Therapies (ACTs) case study: has high potential, with opportunities to reduce cycle times and inventory, by adopting continuous processes that also reduce solvent use. Several competing technology developments are being considered with maturing technology readiness levels, which suggest promising routes to commercialisation are possible.

Discussion: The current batch process involves cultivation (e.g. planting, growing, harvesting), then extraction using solvents, which is costly, and poses safety, environmental and product quality risks [38]. The total cycle time from planting to shipping is normally in excess of 14 months. A bioprocessing route has also been developed and commercialised (and qualified as an alternative source for Case 2based derivatives in 2013 by the WHO). However the cost of goods remains high and is similar to plantderived sources $(\$ 350-400 / \mathrm{kg})$. Capacities via this route are in the range of $50-60 \mathrm{MT}$ (It is estimated that global capacity will remain $\sim 200 M T)$. On-going studies have outlined a series of continuous and hybrid routes, from synthesis (cutting lead times in the range of 30-90 days, currently, to 5-10 days) through to pack and distribution - with the potential of reducing overall cycle times (raw materials to pack) to 10 s of weeks [3].

Advances in continuous formulation to increase the bioavailability of APIs would significantly help reduce overall cost of goods and improve treatment adherence. The 'pill burden' may be significantly reduced, thereby, maximising the impact of benefit for patients and health providers. 
Alternative network design options, exploring new technologies (e.g. inkjet printing) with respect to pack design [26], have a significant opportunity in terms of supply chain and distribution, improving security and enabling health agencies to access better data.

- $\quad$ Case 3 - Diabetes drug case study: has the highest potential for a switch to continuous granulation supporting smaller plant footprints with associated capital cost reductions. The simpler chemistry involved in this case study and a significantly growing demand (requiring more capacity), where volume projections suggest a doubling of demand by 2035 ; contribute to a potentially attractive batch-tocontinuous transformation agenda.

Discussion: Having uninterrupted supply offers downstream inventory improvement, in the case of case 3, as opposed to cycle time gains presented for cases 1 and 2. As demand continues to increase (double-digits year-on-year), there are significant benefits in terms of \% inventory and the management of E2E supply - given the volume and scale flexibilities afforded by continuous processing [1], [27], [28].

The case studies are exploratory in nature and seek to demonstrate a methodology for identifying potential opportunity areas. The analysis suggests that the methodology can help to reveal reconfiguration opportunities that support re-integration of these sub-systems and deliver enhanced business performance that can also have societal benefits. In reviewing the assessments emerging from the analysis, the discussions above suggest the initial conclusions from this study are broadly supported. This further underpins the conclusions from the analytical approach set out above.

In conclusion, previous research studies confirm that many industrial systems comprise of semi-independent sub-systems that have evolved over extended time periods but have then become part-disconnected, operating as silos of activity with independent governance and coordination mechanisms [17], [25]. In many cases, the regulatory frameworks 'lock-in' this structural development. An analytical framework, applicable to multiple industrial contexts is presented and applied which considers reconfiguration opportunities that adopt a systems perspective rather than incremental optimisation at the sub-system level. At a broader level, the study identifies the potential to reconfigure and re-integrate sub-systems by enabling a deeper understanding of the drivers of, and interactions between, the main sub-systems that make up complex, multi-tier supply chains. 


\section{LIMITATIONS AND FUTURE WORK}

The work is part of an on-going research agenda that seeks to develop next generation Pharmaceutical supply chains. This involves extending the preliminary analysis conducted for selected patient populations and productprocess archetypes identified as having attractive business/value propositions and promising technological feasibility. The application of the methodology in three exploratory cases is used to demonstrate utility and some level of generalisability. Further case studies would indeed be expected (and are planned) as part of an extended testing regime. Consideration of the behavioural changes and dynamic capabilities required to make the transformation to continuous processing manufacturing models will be developed as part of future activity.

\section{ACKNOWLEDGEMENTS}

We would like to acknowledge the support from the UK's EPSRC Centre for Innovative Manufacturing in Continuous Manufacturing and Crystallisation, and the Advanced Manufacturing Supply Chain Initiative (AMSCI) programme Remedies Project.

\section{References:}

[1] Srai, J.S., Badman, C., Krumme, M., Futran, M., Johnston, C., 2015. Future supply chains enabled by continuous processing-opportunities and challenges. May 20-21, 2014. Continuous Manufacturing Symposium. J. Pharm. Sci., Article first published online: 28th January 2015. doi: 10.1002/jps.24343.

[2] Ripin, SJ., Jamieson, D., Meyers, A., Warty, U., Dain, M., Khamsi (2014) 'Antiretroviral procurement and supply chain management' ,Antiviral Therapy. Vol. 19 Suppl. 3, pp.79-89.

[3] Harrington, T.S., Srai, J.S. (2015) 'Reconfiguring pharmaceutical value chains through crystallisation-based technology interventions', Org. Process Res. Dev. (in review)

[4] Langlois, R.N. 1992. Transaction cost economics in real time. Industrial and Corporate Change 1: 99-127

[5] Jacobides M.G., 2005. Industry change through vertical disintegration: How and why markets emerged in mortgage banking. Academy of Management Journal 48(3): 465-498.

[6] Gereffi G, Humphrey J, Sturgeon T., 2005. The governance of global value chains. Review of International Political Economy 12:78-104.

[7] Sturgeon, T., 2001: How do we define value chains and production networks? Special Working papers series, MIT IPC Globalization Working Paper 00-010

[8] Kaplinsky, R. and Morris M., 2001, A Handbook for Value Chain Research, prepared for the IDRC, Institute of Development Studies: Sussex

[9] Mudambi, R., and Venzin, M., 2010. The strategic nexus of offshoring and outsourcing decisions, Journal of Management Studies, Special issue: Offshoring and outsourcing, 47(8): 1510-1533.

[10] Srai, J.S. and Alinaghian, L.S., 2013. Value chain reconfiguration in highly disaggregated industrial systems: examining the emergence of healthcare diagnostics. Global Strategy Journal, 3: 88-108.

[11] Srai, J.S., Gregory M.J., 2008. A Supply Network Configuration Perspective on International Supply Chain Development. International Journal of Operations Management, vol. 5 (May 2008)) 386-411.

[12] Srai, J.S., 2013. Value-chain configurations of emerging country multinationals. In The Competitive advantage of emerging market multinationals, Williamson PJ, et al. Cambridge University Press. 
[13] Calabrese, G.S., Pissavini, S., 2011. From batch to continuous flow processing in chemical manufacturing, AIChE Journal, 57(4): 828-834.

[14] Roberge, D., Durcy, L., Bieler N., Cretton P., Zimmermann B., 2005. Microreactor Technology: A Revoltion for the Fine Chemical and Pharmaceutical Industries. Chemical Engineering Technology. 25 pp. 318-322

[15] Gorsek, A. and Glavic, P., 2000. Design of batch versus continuous processes Part III, Trans IChemE, 78, Part A, March

[16] Seifert, T., Sievers, S., Bramsiepe, C., Schembecker, G., 2012. Small scale, modular and continuous: A new approach in plant design, Chemical Engineering and Processing, 52, pp. 14-150.

[17] Srai, J.S., and Christodoulou, P., 2014. 'Capturing Value from Global Networks; Strategic approaches to configuring international production, supply and service operations', University of Cambridge IfM Publication ISBN: 978-1-902546-30-8.

[18] Johnson, M. (2012) Design and Scale Up of Fully Continuous Processes including Reaction, Workup, and Isolation, AIChE Process Development Symposium, June 5-7th, PA

[19] Pharmafile (2013) Pharma makes progress on continuous processing. Available at: http://www.pharmafile.com/news/181079/pharma-makes-progress-continuous-processing (accessed 13.04.15)

[20] Lonza (2015) Continuous Flow Technologies. Available at: http://www.lonza.com/custommanufacturing/chemical-manufacturing/advanced-chemical-synthesis-acs/continuous-flow-technologies.aspx (accessed 13.04.15)

[21] Mascia et al., (2013) 'End-to-end continuous manufacturing of pharmaceuticals: integrated synthesis, purification and final dosage formation', Angew. Chem. International Edition, Vol. 52, 12359-12363.

[22] Pfizer (2015) Pfizer Ireland Operations. Available at: http://www.pfizer.ie/operations.cfm (accessed 13.04.15)

[23] Genzyme (2015) Company Info. Available at: http://www.genzyme.co.uk/corp-info/genzyme-uk/haverhill.aspx (accessed 13.04.15)

[24] Chimica Oggi (2013) 5th Symposium on Continuous Flow Reactor Technology for Industrial Applications. Available at: http://www.flowchemistrytks.com/LP/report/5_CO6_2013_RGB_35-44.pdf (accessed 13.04.15)

[25] Srai, J. S., Harrington, T.S., Alinaghian, L.S., 2014, An approach to exploring integration benefits of continuous flow technologies within Pharmaceutical supply chains, Monographic supplement series of Chimica Oggi/ Chemistry Today Vol 32 (4), Jul/Aug 14-19

[26] Daly, R., Harrington, T.S., Martin, G.D., Hutchings, I.M. (2015) 'Inkjet printing for pharmaceutics - A review of research and manufacturing', International Journal of Pharmaceutics. Article published online: 12th March. DOI: 10.1016/j.ijpharm.2015.03.017

[27] BCG (2013) 'Rethinking the Pharma supply chain: new models for a new era'. May 2013.

[28] McKinsey (2010) 'Outlook on Pharma Operations'. Available at: www.mckinsey.com

[29] Gilead corporate website. Accessed on 05/12/2014 at: http://www.gilead.com

[30] Consolidated Guidelines On The Use Of Antiretroviral Drugs For Treating And Preventing HIV Infection Recommendations For A Public Health Approach - June 2013, WHO

[31] WHO HIV/AIDS Global Pricing Report Mechanism, accessed on 05/12/2014 at: http://apps.who.int/hiv/amds/price/hdd/

[32] Pinheiro, E., Antunes, O., \& Fortunak, J. (2008). A survey of the syntheses of active pharmaceutical ingredients for antiretroviral drug combinations critical to access in emerging nations. Antiviral Research, 79(3), 143-165

[33] Crawford, KW., Ripin, DHB., Levin, AD., Campbell, JR and Flexner, C. 2012. Optimising the manufacture, formulation, and dose of antiretroviral drugs for more cost-efficient delivery in resource-limited settings: a consensus statement. The Lancet Infectious Diseases. 12(7): 550-560

[34] de Treville S, Shapiro R D, Hameri A-P. 2004. From supply chain to demand chain: the role of lead time reduction in improving demand chain performance. Journal of Operations Management 21 (2004) 613-627

[35] World Malaria Report: 2013, WHO, Geneva. Accessed on 10/12/2014 at: http://www.who.int/malaria/publications/world_malaria_report/en/

[36] Artemisinin Conference 2014: China. Accessed on 10/12/2014 at: http://www.a2s2.org/conferences/2014artemisinin-conference,-china/

[37] Fact Sheet, ACT Prices under the Affordable Medicines Facility Malaria: Update of 22 May 2013, The Global Fund. Accessed on 10/12/2014

[38] Gilmore K, Kopetzki D, Lee JW, Horváth Z, McQuade DT, Seidel-Morgenstern, Seeberger PH. 2014. Chem. Commun. 50, 12652-12655

[39] Conference Report, Artemisinin Conference 2013: Nairobi. Accessed 10/12/2014 at: http://www.a2s2.org/conferences/artemisinin-conference-2013,-kenya/

[40] Doughty D, Robertson J. (2013) 'Continuous Granulation'. Proceedings of The Science of Medicines, Heriot Watt University, 2-4th September.

[41] Turnbull N, Boxell K, (2013) 'Continuous Processing of Pharmaceutical Wet Granulation Formulations Conversion of Batch to Continuous Manufacturing Design'. Proceedings of The Science of Medicines, Heriot Watt University, 2-4th September.

[42] Schoeters, K. (2014) 'Continuous Granulation: A Case Study', GEA website 14 Nov 2014. http://www.gea.com/global/en/stories/continuous-granulation.jsp

[43] International Diabetes Federation. 2014. IDF Diabetes Atlas, Sixth edition. Accessed on 5/12/2014 at: http://www.idf.org/sites/default/files/Atlas-poster-2014 EN.pdf 
[44] Business World. 2013. The rise of API barons. Accessed on 5/12/2014 at: http://www.businessworld.in/news/pharma/the-rise-of-api-barons/745982/page-2.html

[45] Metformin: Medline Plus information. US National Library of Medicine, National Institute of Health. Accessed on 3/04/2015 at: http://www.nlm.nih.gov/medlineplus/druginfo/meds/a696005.html

[46] Shalmashi, A. (2008) 'New route to Metformin Hydrochloride synthesis', Molbank, M564; doi:10.3390/M564

[47] Aron SARL, Procédé de parapration de chlorhydrate de diméthylbiguanide. French Patent No. 7527350 $(91 / 04 / 1977)$

[48] Hasan M R et al Preparation of Metformin Hydrochloride Extended Release Matrix Tablets by Direct Compression Method and Its In vitro Evaluation. British journal of Pharmaceutical Research 4(24): 2679 2693, 2014)

Appendix A: Expert informants, by role, and their contribution to the 3 case studies

\begin{tabular}{|c|c|c|}
\hline $\begin{array}{c}\text { Interviewee } \\
\text { /Sources }\end{array}$ & Role/contribution area & Organisation \\
\hline A & Former head of Global supply chain \\
- ARVs & Multi-national Pharma \\
\hline B & Former head of Global supply chain & Multi-national Pharma \\
\hline C & $\begin{array}{r}\text { Former supply chain/technical expert } \\
- \text { anti-Malarial products }\end{array}$ & $\begin{array}{c}\text { Multiple, including Malaria Medicines } \\
\text { Ventures (MMV) and Assured } \\
\text { Artemisinin Supply System (A2S2) }\end{array}$ \\
\hline D & $\begin{array}{r}\text { Continuous flow technologies - } \\
\text { specialising in anti-Malarial products }\end{array}$ & Academia \\
\hline E & $\begin{array}{r}\text { Continuous manufacturing technologies - } \\
\text { diabetes context as part of this study }\end{array}$ & Multiple Academia \\
\hline F & $\begin{array}{r}\text { Global supply chain and strategy - } \\
\text { diabetes context as part of this study }\end{array}$ & Multi-national Pharma \\
\hline
\end{tabular}

